\title{
Screening COPD (Chronic Obstructive Pulmonary Disease) Patients for lung Cancer
}

\author{
Syed Nisar Ahmad1*, Sajad Ahmad Bhat ${ }^{2}$, Shaheena Parveen ${ }^{3}$, Showkat Ali Mufti, \\ Ashok Kumar Shah 5
}

${ }^{1 *} \mathrm{MD}, \mathrm{DM}$, Consultant Medical Oncologist, Government Medical College, Srinagar, J\&K, India. 2PhD Scholar Medical Biochemistry, SGT Medical College, Gurgaon, Haryana, India.

3MD, DM, Lecturer Department of Medicine, Government Medical College, Srinagar, J\&K, India. ${ }^{4} \mathrm{MD}, \mathrm{MRCP}$, Professor \& Head, Department of Emergency Medicine, SKIMS, Srinagar, J\&K, India. ${ }^{5}$ Tutor, Department of Biochemistry, SGT Medical College, Gurgaon, Haryana, India.

\begin{abstract}
Introduction: Patients with chronic obstructive pulmonary disease (COPD) are at increased risk for both the development of primary lung cancer, as well as poor outcome after lung cancer diagnosis and treatment. The present study was undertaken to screen COPD patients for lung cancer and to find clinical and laboratory correlates of lung cancer in patients of COPD.
\end{abstract}

Material and Methods: The present hospital based study comprised of 200 consecutive patients suffering with COPD. The patients were subjected to chest - radiography (both posteroanterior and lateral views), sputum cytology, fibre optic bronchoscopy and high resolution computed tomography (HRCT). Data was analyzed by standard statistical procedure using descriptive statistics method and comparisons were made by using chi-square test, and odds ratio. A 'p' value of < 0.05 was taken as statistically significant.

Results: Among the various screening modalities used in this study, sputum cytology provided the lowest sensitivity (33.33\%) and specificity $(67.67 \%)$ while HRCT chest afforded the best sensitivity (91.7\%) and specificity (95.7\%). The variables significantly associated with lung cancer in our study were smoking, anorexia, anemia, weight loss, clubbing, and indices of lung function tests.

\section{INTRODUCTION}

Patients with chronic obstructive pulmonary disease (COPD) are at increased risk for both the development of primary lung cancer, as well as poor outcome after lung cancer diagnosis and treatment. ${ }^{1}$ COPD was the third most common cause of death worldwide in 2010 and ranked fifth worldwide in terms of burden of disease. ${ }^{2}$ Chronic inflammation associated with COPD likely plays a role in the pathogenesis of lung cancer, just as chronic inflammation contributes to malignant transformation in other organs. Inflammation in COPD may result in repeated airway epithelial injury and accompanying high cell turnover rates and propagation of DNA errors resulting in amplification of the carcinogenic effects of cigarette smoke. ${ }^{1}$ Cigarette smoking is an important risk factor for COPD and lung cancer. COPD is an independent risk factor for lung carcinoma, particularly for
Conclusion: In conclusion, patients with COPD constitute a group at high risk for lung cancer. Screening these patients, particularly those with increasing severity of obstruction is worthwhile in as much as it has the promise of early detection and consequently early treatment and improved survival. Chest CT appears to be the best screening procedure given its excellent sensitivity and specificity.

Keywords: Chronic obstructive pulmonary disease; Lung Carcinoma; Chest CT.

\section{${ }^{*}$ Correspondence to}

Dr. Syed Nisar Ahmad,

Consultant Medical Oncologist,

Department of Medicine,

Govt. Medical College, Srinagar, J\&K, India.

\section{Article History:}

Received: 27-09-2016, Revised: 05-10-2016, Accepted: 11-11-2016

\begin{tabular}{|l|r|}
\hline \multicolumn{2}{|c|}{ Access this article online } \\
\hline $\begin{array}{l}\text { Website: } \\
\text { www.ijmrp.com }\end{array}$ & Quick Response code \\
\hline DOl: & \\
10.21276/ijmrp.2016.2.6.035 &
\end{tabular}

squamous cell carcinoma ${ }^{3}$ and the risk of lung cancer increases up to five times in smokers with airflow obstruction than those with normal lung function. ${ }^{4}$ The present study was undertaken to Screen COPD patients for lung cancer and to find clinical and laboratory correlates of lung cancer in patients of COPD.

\section{MATERIAL AND METHODS}

The present hospital based study comprised of 200 consecutive patients suffering with COPD enrolled from both outpatient and inpatient (wards) departments at Sher -I - Kashmir Institute of Medical Sciences. An informed consent was obtained from the patients. The study was approved by the Institutional ethical Review Board. The patients included in the study were men and women (both smokers and nonsmokers) aged 40 years or more 
with history suggestive of COPD (cough with sputum production in chronic bronchitis and breathlessness in emphysema), physical findings suggestive of airway obstruction (rhonchi, decreased intensity of breath sounds, and prolonged expiration). Patients with radiological evidence of significant lung disease (e.g. pneumonia, heart failure, pulmonary embolism) were excluded from the study. The patients were subjected to chest radiography (both posteroanterior and lateral views), sputum cytology, fibre optic bronchoscopy and high resolution computed tomography (HRCT).

Statistical Methods: Data was analyzed by standard statistical procedure using descriptive statistics method and comparisons were made by using chi-square test, and odds ratio. A ' $p$ ' value of $<0.05$ was taken as statistically significant.

\section{OBSERVATIONS}

Table 1 shows the clinical details of the patients studied. Expectedly nearly all the patients had cough, expectoration, and breathlessness.

About a half of the patients had breathlessness for $6-10$ years at the time of study. Three fourths of the patients had 1-5 exacerbations of COPD in the preceding two years and about two thirds had been admitted to hospital once or twice in the preceding five years.

Two thirds of the patients had abnormal shape of chest; two thirds had abnormal findings on chest auscultation. There was a significant correlation between haemoptysis, number of hospital admissions, weight loss, anorexia, anemia (pallor), clubbing and chest shape with malignancy.

Table 1: Clinical profile and Hospital admissions in Relation to malignancy

\begin{tabular}{|c|c|c|c|c|c|}
\hline \multirow{2}{*}{ Symtom/Sign } & & \multicolumn{2}{|c|}{ Malignancy } & \multirow[t]{2}{*}{ OR } & \multirow[t]{2}{*}{ p.value } \\
\hline & & Present & Absent & & \\
\hline \multirow[t]{2}{*}{ Cough } & $\mathbf{P}$ & $12(100 \%)$ & $186(98.9 \%)$ & & $>0.05$ (NS) \\
\hline & A & $0(0)$ & $2(1.1 \%)$ & & \\
\hline \multirow[t]{2}{*}{ Expectoration } & $\mathbf{P}$ & $12(100 \%)$ & $171(91.0 \%)$ & & $>0.05(\mathrm{NS})$ \\
\hline & A & $0(0)$ & $17(9.0 \%)$ & & \\
\hline \multirow[t]{2}{*}{ BLN } & P & $11(91.7 \%)$ & $175(93.1 \%)$ & & $>0.05(\mathrm{NS})$ \\
\hline & A & $1(8.3 \%)$ & $13(6.9 \%)$ & & \\
\hline Duration of & $<5 y r$ & $2(16.7 \%)$ & 71 (37.8\%) & 3.03 & $>0.05$ (NS) \\
\hline BLN & $>5 y r$ & $10(83.3 \%)$ & $117(62.2 \%)$ & & \\
\hline \multirow[t]{2}{*}{ Heamoptysis } & P & $3(25 \%)$ & $14(7.4 \%)$ & 4.14 & $<0.05(\mathrm{Siq})$ \\
\hline & A & $9(75 \%)$ & $174(92.6 \%)$ & & \\
\hline \multirow{2}{*}{$\begin{array}{l}\text { No. of exacerbations } \\
\text { for last } 2 \text { yrs }\end{array}$} & $\leq 5$ & $8(66.7 \%)$ & $157(83.5 \%)$ & 2.53 & $>0.05$ (NS) \\
\hline & $>5$ & $4(33.3 \%)$ & $31(16.5 \%)$ & & \\
\hline \multirow[t]{2}{*}{ No. of Hospital admissions } & $\leq 2$ & $4(33.3 \%)$ & $145(77.1 \%)$ & 6.74 & $<0.05$ (Sig) \\
\hline & $>2^{*}$ & $8(66.7 \%)$ & $43(22.9 \%)$ & & \\
\hline \multirow[t]{2}{*}{ Wt. loss } & $\mathbf{P}$ & $9(75.0 \%)$ & $57(30.3 \%)$ & 6.90 & $<0.05$ (sig) \\
\hline & A & $3(25.0 \%)$ & $131(69.7 \%)$ & $(-1.1-5.6)$ & \\
\hline \multirow[t]{2}{*}{ Anorexia } & $\mathbf{P}$ & $9(75.0 \%)$ & $84(44.7 \%)$ & 3.71 & $<0.05(\mathrm{Sig})$ \\
\hline & A & $3(25.0 \%)$ & $104(55.3 \%)$ & $(-0.5-6.2)$ & \\
\hline \multirow[t]{2}{*}{ Pallor } & $\mathbf{P}$ & $9(75.0 \%)$ & $44(23.4 \%)$ & 9.82 & $<0.05$ (sig) \\
\hline & A & $3(25.0 \%)$ & $144(76.6 \%)$ & $(-1.3-5.4)$ & \\
\hline \multirow[t]{2}{*}{ Cyanosis } & $\mathbf{P}$ & $2(16.7 \%)$ & $20(10.6 \%)$ & 1.68 & $>0.05$ (NS) \\
\hline & A & $10(83.3 \%)$ & $168(89.4 \%)$ & & \\
\hline \multirow[t]{2}{*}{ Icterus } & $\mathbf{P}$ & $0(0)$ & $5(2.7 \%)$ & & $>0.05$ (NS) \\
\hline & A & $12(100 \%)$ & $183(97.3 \%)$ & & \\
\hline \multirow[t]{2}{*}{ Clubbing } & $\mathbf{P}$ & $10(83.3 \%)$ & $15(8.0 \%)$ & 57.7 & $<0.05(\mathrm{Sig})$ \\
\hline & A & $2(16.7 \%)$ & $173(92.0 \%)$ & & \\
\hline \multirow[t]{2}{*}{ Flap } & $\mathbf{P}$ & $0(0)$ & $9(4.8 \%)$ & & $>0.05$ (NS) \\
\hline & A & $12(100.0 \%)$ & 179 (95.2) & & \\
\hline \multirow[t]{2}{*}{ JVP } & $\mathbf{P}$ & $0(0)$ & $6(3.2 \%)$ & & $>0.05$ (NS) \\
\hline & A & $12(100.0 \%)$ & $182(96.8 \%)$ & & \\
\hline \multirow[t]{2}{*}{ LAP } & $\mathbf{P}$ & $1(8.3 \%)$ & $4(2.1 \%)$ & 4.18 & $>0.05$ (NS) \\
\hline & A & $11(91.7 \%)$ & $184(97.9 \%)$ & & \\
\hline \multirow[t]{2}{*}{ Skin changes } & $\mathbf{P}$ & $2(16.7 \%)$ & $9(4.8 \%)$ & 3.98 & $>0.05$ (NS) \\
\hline & A & $10(83.3 \%)$ & $179(95.2 \%)$ & & \\
\hline \multirow[t]{2}{*}{ Breath sounds } & Normal & $2(16.7 \%)$ & 71 (37.8\%) & 3.03 & $>0.05$ (NS) \\
\hline & Added sounds & $10(83.3 \%)$ & $117(62.2 \%)$ & & \\
\hline \multirow[t]{2}{*}{ CVS } & NAD & $7(58.3 \%)$ & $144(76.6 \%)$ & 2.34 & $>0.05$ (NS) \\
\hline & PAH & $5(41.7 \%)$ & $44(23.4 \%)$ & & \\
\hline \multirow[t]{2}{*}{ Chest shape } & Norma & $1(8.3 \%)$ & $84(44.7 \%)$ & 8.8 & $<0.05$ (sig) \\
\hline & Barrel/flat $^{*}$ & $11(91.7 \%)$ & $104(55.3 \%)$ & & \\
\hline
\end{tabular}

$\mathrm{P}=$ Present, $\mathrm{A}=\mathrm{Absent}, \mathrm{N}=$ Normal, $\mathrm{BLN}=$ Breathlessness, LAP=Lymphadenopathy, NAD=No abnormality detected, $\mathrm{PAH}=$ Pulmonary artery hypertension. 
Table 2: X-Ray chest in relation to malignancy in studied subjects

\begin{tabular}{|c|c|c|c|c|c|}
\hline & \multicolumn{2}{|c|}{ Malignancy } & \multirow[b]{2}{*}{$\begin{array}{c}\text { Total } \\
n=200\end{array}$} & \multirow[b]{2}{*}{$\mathrm{OR} / \mathrm{X}^{2}$} & \multirow[b]{2}{*}{$P$ value } \\
\hline X-Ray & $\begin{array}{c}\text { Present } \\
n=12\end{array}$ & $\begin{array}{c}\text { Absent } \\
n=188\end{array}$ & & & \\
\hline Normal & $3(25.0 \%)$ & $131(69.7 \%)$ & $134(67.0 \%)$ & $X 2=37.086$ & $P=0.000$ \\
\hline Indeterminate & $3(25.0 \%)$ & $49(26.1 \%)$ & $52(26.0 \%)$ & & (sig) \\
\hline $\begin{array}{l}\text { suspicious } \\
\text { X-Ray (clubbed) }\end{array}$ & $6(50.0 \%)$ & $8(4.3 \%)$ & $14(7.0 \%)$ & & \\
\hline Abnormal * & $9(75.0 \%)$ & $57(30.3 \%)$ & $66(33 \%)$ & $\mathrm{OR}=6.989$ & $P<0.05$ (sig) \\
\hline Normal & $3(25.0 \%$ & $131(69.7 \%)$ & $134(67 \%)$ & & \\
\hline
\end{tabular}

Table 3:.Sputum cytology in the studied patients and in relation to malignancy

\begin{tabular}{lcccc}
\hline & Total & Present & Absent & Results \\
\hline Sputum cytology & & & & \\
$\quad$ Normal or slight atypia & $194(97.0 \%)$ & $8(66.7 \%)$ & $186(98.9 \%)$ & $\mathrm{X}^{2}=46.275$ \\
Moderate to severe atypia & $4(2.0 \%)$ & $2(16.7 \%)$ & $2(1.1 \%)$ & $\mathrm{P}=0.000(\mathrm{Sig})$ \\
$\quad$ Malignant cell present & $2(1.0 \%)$ & $2(16.7 \%)$ & $0(0.0)$ & \\
Sputum cytology (Clubbed) & & & & \\
Abnormal & $6(3 \%)$ & $4(33.3 \%)$ & $2(1.1 \%)$ & $\mathrm{OR}=46.50$ \\
$\quad$ Normal & $194(97 \%)$ & $8(66.7 \%)$ & $186(98.8 \%)$ & $\mathrm{p}<0.05(\mathrm{sig})$ \\
\hline
\end{tabular}

Table 4: Co-relation between bronchoscopy and lung cancer

\begin{tabular}{|c|c|c|c|c|c|c|c|}
\hline & & \multirow{2}{*}{\multicolumn{2}{|c|}{$\begin{array}{l}\text { Total } \\
n=60\end{array}$}} & \multicolumn{4}{|c|}{ Malignancy } \\
\hline & & & & \multicolumn{2}{|c|}{$\begin{array}{c}\text { Present } \\
n=12\end{array}$} & \multicolumn{2}{|c|}{$\begin{array}{c}\text { Absent } \\
n=48\end{array}$} \\
\hline & & $\mathbf{N}$ & $\%$ & $\mathrm{n}$ & $\%$ & $\mathrm{n}$ & $\%$ \\
\hline \multirow[t]{3}{*}{ Hyperemia } & Present & 26 & 43.3 & 12 & 20.0 & 14 & 23.3 \\
\hline & Absent & 34 & 56.7 & 0 & $(0.0)$ & 34 & 56.7 \\
\hline & Total & 60 & 100.0 & 12 & 20.0 & 48 & 80.0 \\
\hline \multirow[t]{3}{*}{ Secretions } & Present & 33 & 55.0 & 12 & 20.0 & 21 & 35.0 \\
\hline & Absent & 27 & 45.0 & 0 & $(0.0)$ & 27 & 45.0 \\
\hline & Total & 60 & 100.0 & 12 & 20.0 & 48 & 80.0 \\
\hline \multirow[t]{3}{*}{ Luminal pathology } & Present & 13 & 21.7 & 10 & 16.7 & 3 & 5.0 \\
\hline & Absent & 47 & 78.3 & 2 & 3.3 & 45 & 75.0 \\
\hline & Total & 60 & 100.0 & 12 & 20.0 & 48 & 80.0 \\
\hline$P$ value & \multicolumn{7}{|c|}{$<0.05$ (p<0.05= sig.) } \\
\hline
\end{tabular}

Chest X-Ray was interpreted as normal in 134(67\%), indeterminate in 52(26\%), and suspicious in $14(7 \%)$ of the patients. Malignancy was detected in $3(2.2 \%), 3(5.7 \%)$, and 6 $(42.85 \%)$ respectively of the subjects having normal, indeterminate, and suspicious chest X- ray (table 2). Chest X Ray findings and malignancy were significantly correlated. Chest X-Ray provided a sensitivity of $75 \%$ and a specifity of $69.7 \%$ for the detection of lung carcinoma giving positive and negative predictive values of 13.63 and $97.76 \%$ respectively.

As shown in table 3, sputum cytology revealed normal results or slight atypia in 194, moderate to severe atypia in 4, and malignant cells in 2; overall sputum cytology was abnormal in 6. Among 194 patients with normal findings or slight atypia on sputum cytology, malignancy was detected in $8(4.3 \%) ; 2$ of the 4 patients with moderate to severe atypia had lung cancer and malignancy was confirmed in both of the patients having malignant cells on sputum cytology. For the detection of lung cancer, sputum cytology was $33.3 \%$ sensitive and $98.8 \%$ specific.
The results of bronchoscopy (table 4) performed on a total of 60 subjects are shown in table 8. Hyperemia was found in 26 including the 12 patients found to have malignancy in this study. Secretions were found in 33 including the 12 with malignancy. Intraluminal pathology was found in 13 including only 10 of the 12 patients detected to have malignancy in our study. Overall, bronchoscopy detected 10 of the 12 patients documented to have malignancy in our study giving a sensitivity of $83.3 \%$; 45 of the 48 patients not having malignancy had bronchoscopy results negative for malignancy giving this procedures a specifity of 93.8\% (table 5). Bronchoalveolar lavage (BAL) revealed malignant cells in 4 of the 12 patients with malignancy (sensitivity 33\%);none of the subjects in whom BAL was negative for malignant cells was proved to have malignancy (specifity $100 \%$ ).

As shown in table 6, CT detected lung cancer in 11 of the 12 subjects with malignancy while only one of the 45 patients with normal CT chest had lung cancer giving this investigation a sensitivity and specifity of $91.7 \%$ and $95.7 \%$ respectively. 
Table 5: Co-relation between Bronchoalveolar lavage(BAL) and lung cancer

\begin{tabular}{lccccc}
\hline & \multicolumn{2}{c}{ Malignancy } & Total & O R & P \\
\cline { 2 - 6 } & Present & Absent & & & \\
Bronchoscopy (for malignancy) & & & & & \\
$\quad+v e$ & $10(83.3 \%)$ & $3(6.3 \%)$ & 13 & 75.00 & $<0.05(\mathrm{sig})$ \\
$\quad$-ve & $2(16.7 \%)$ & $45(93.8 \%)$ & 47 & & \\
BAL for Malignant cells & & & & & \\
$\quad$ Present & $4(33.3 \%)$ & $0(0.0)$ & 4 & 45.0 & $<0.05(\mathrm{sig})$ \\
$\quad$ Absent & $8(66.7 \%)$ & $45(100.0 \%)$ & 53 & & \\
\hline
\end{tabular}

$\mathrm{BAL}=$ Bronchoalveolar lavage

Table 6: Relationship between CT Scan chest and malignancy.

\begin{tabular}{lccccc}
\hline CT Chest & \multicolumn{3}{c}{ Malignancy } & p.value \\
\cline { 2 - 4 } & Present & Absent & Total & OR & \\
Normal & $1(8.3 \%)$ & $44(95.7 \%)$ & 45 & & \\
Mass lesion* & $11(91.7 \%)$ & $2(4.3 \%)$ & 13 & 242.0 & $<0.05$ sig. \\
Total & 12 & 46 & 58 & & \\
\hline
\end{tabular}

\section{DISCUSSION}

For present study, we used chest X-Ray, sputum cytology, bronchoscopy, and HRCT to screen patients with COPD for lung cancer. Other studies have used these same modalities singly or in various combinations. Bechtal $\mathrm{JJ}$ et $\mathrm{al}^{5}$ used chest X-ray, sputum cytology, and CT chest to screen 88 patients with COPD for lung cancer.

Nearly half $(42.85 \%)$ of all the patients in whom chest X-Ray was interpreted as suspicious were detected to have lung cancer in our study. The close association between COPD and lung cancer suggests either that there may be common susceptibilities of these diseases to the effects of cigarette smoking or that abnormalities in the COPD lung somehow favor the development of lung cancer beyond the effect of smoking alone. ${ }^{6}$

Out of 194 subjects in whom sputum cytology was normal or showed mild atypia, $4.12 \%$ had lung cancer in our study; in contrast lung cancer was found in 2 of 4 with moderate to severe atypia and in both the patients in whom sputum revealed malignant cells. In an earlier study sputum cytology revealed similar results, $95.89,4$, and $0.11 \%$ having normal cytology or slight atypia, moderate or more severe atypia, and malignant cells respectively; all 11 patients with malignant cells on sputum cytology and 6 of 14 patients- $43 \%$-with marked atypia had lung cancer. $^{7}$

The marginal differences likely stem from a marked difference in sample size in the two studies. The sensitivity of sputum cytology for detection of lung cancer in our study was $33.3 \%$ (4 of the 12 cases were detected by sputum cytology which was performed in all the patients). Other studies have reported a sensitivity of 25$49 \%$ for this investigation in the detection of lung cancer. ${ }^{7-9}$ The difference in the sensitivity reported likely emanate from differences in the sample size and in the yield of sputum for cytological examination in patients with COPD.

In the present study bronchoscopy had a sensitivity of $83.33 \%$ and a specificity of $93.8 \%$ in the detection of lung cancer. A questionnaire, self-administered in a primary care office setting, helps identify patients at high risk of lung cancer. If upcoming results of randomized controlled trials show a benefit of lung screening, this tool could be of help to select patients for screening. ${ }^{10}$

In 13 of the 58 patients in whom it was obtained, HRCT chest detected lesions in the lung; 11 of these 13 patients had lung malignancy. One of the 12 patients with lung cancer in our study had normal HRCT chest; the cancer in this patient was revealed by bronchoscopy. This gave CT a sensitivity and specificity of $91.7 \%$ and $95.7 \%$ respectively, which were the highest for any modality in our study.

Swensen SJ et al ${ }^{11}$ showed that screening with spiral CT can detect lung cancer at smaller size and earlier stage than can be done with chest radiography; the $92 \%$ sensitivity of CT for detecting lung cancer reported by them is similar to that found in our study Thus, CT can detect lung cancer at an early stage and results in increased survival with the consequent early treatment. ${ }^{12}$ The clinical characteristics found to be associated with lung cancer in our study were haemoptysis, number of hospital admissions, weight loss, anorexia, anemia, clubbing, and abnormal chest shape.

The limitation of the present study was our inability to perform bronchoscopy and HRCT in all the patients studied that would likely have caused and underestimation of the prevalence of lung cancer in patients screened in this study.

\section{CONCLUSION}

Among the various screening modalities used in this study, sputum cytology provided the lowest sensitivity (33.33\%) and specificity (67.67\%) while HRCT chest afforded the best sensitivity $(91.7 \%)$ and specificity $(95.7 \%)$. The variables significantly associated with lung cancer in our study were smoking, anorexia, anemia, weight loss, clubbing, and indices of lung function tests. In conclusion, patients with COPD constitute a group at high risk for lung cancer. Screening these patients, particularly those with increasing severity of obstruction is worthwhile in as much as it has the promise of early detection and consequently early treatment and improved survival. Chest CT appears to be the best screening procedure given its excellent sensitivity and specificity. 


\section{REFERENCES}

1. Stacy R, Hawkins KA, DeCamp MM, Kalha R. Lung Cancer in Chronic Obstructive Pulmonary Disease Enhancing Surgical Options and Outcomes. Am J Respir Crit Care Med 2011; 183(9):1138-46.

2. Durham AL, Adcock IM. The relationship between COPD and lung cancer. Lung Cancer (Amsterdam, Netherlands). 2015; 90(2):121-127.

3. Papi A. COPD increases the risk of squamous histological subtype in smokers who develop non-small cell lung carcinoma. Thorax 2004;59(8):679-681.

4. Young RP, Hopkins R.J. Link between COPD and lung cancer. Respir Med 2010; 104(5):758-759.

5. Bechtel JJ, Kelley WA, Coons TA, Klein G, Slagel DD, Petty TL. Lung Cancer Detection in Patients With Airflow Obstruction Identified in a Primary Care Outpatient Practice. Chest 2005; 127(4):1140-5.

6. Barnes PJ, Adcock IM. Chronic Obstructive Pulmonary Disease and Lung Cancer: A Lethal Association. American journal of respiratory and critical care medicine 2011; 184:866-7.

7. Skillrod DM, Offord KP, Rochester DM, Minnessota. Higher risk of lung cancer in chronic obstructive pulmonary disease. Annals of Internal Medicine 1986; 105(4):503-7.

8. Jemal A, Tiwari RC, Murray T et al. Cancer Statistics 2004. Cancer 2004:54: 8

9. Frost JK, Ball WC, Levin ML, et al. Early lung cancer detection: results of the initial (prevalence) radiologic and cytologic screening in the John Hopkins study. Am Rev Respir Dis 1984; 130:549-54.
10. Bechtel JJ, Kelley WA, Coons TA, Mohler P, Mohler A, James $D$, Petty TL. Five-Year Outcome of Lung Cancer Detection in Patients With and Without Airflow Obstruction in a Primary Care Outpatient Practice. J Thorac Oncol 2009; 4:1347-51.

11. Swensen SJ, Jett JR, Hartman TE, Midthun DE, Sloan JA, Sykes AM, Aughenbaugh GL, Clemens MA. Lung cancer screening with CT: Mayo Clinic experience 1. Radiology 2003; 226(3):756-61.

12. Kennedy TC, Proudfoot SP, Franklin WA, Merrick TA, Saccomanno G, Corkill ME, Mumma DL, Sirgi KE, Miller YE, Archer PG, Prochazka A. Cytopathological analysis of sputum in patients with airflow obstruction and significant smoking histories. Cancer research. 1996 Oct 15; 56(20):4673-8.

Source of Support: Nil. Conflict of Interest: None Declared. Copyright: (c) the author(s) and publisher. IJMRP is an official publication of Ibn Sina Academy of Medieval Medicine \& Sciences, registered in 2001 under Indian Trusts Act, 1882. This is an open access article distributed under the terms of the Creative Commons Attribution Non-commercial License, which permits unrestricted non-commercial use, distribution, and reproduction in any medium, provided the original work is properly cited.

Cite this article as: Syed Nisar Ahmad, Sajad Ahmad Bhat, Shaheena Parveen, Showkat Ali Mufti, Ashok Kumar Shah. Screening COPD (Chronic Obstructive Pulmonary Disease) patients for lung cancer. Int J Med Res Prof. 2016; 2(6):167-71. DOI:10.21276/ijmrp.2016.2.6.035 